UDC 546.175: 351.773.1: 641.31

DOI: $10.21668 /$ health.risk/2018.4.09.eng

Read

online

\title{
ASSESSMENT OF RISKS CAUSED BY IMPACTS EXERTED ON A HUMAN BODY BY NITRATES CONTAINED IN FOOD PRODUCTS
}

\author{
I.P. Saldan, O.I. Shved, B.A. Balandovich, A.S. Nagornyak, O.N. Mazko, O.G. Makarova, \\ S.P. Filippova, O.V. Zhukova, N.Yu. Potseluev
}

Altai State Medical University, 40 Lenina avenue, Barnaul, 656038, Russian Federation

Food products contamination with xenobiotics of various genesis exerts negative influence on population health. According to multiple research performed on various territories in Russia, nitrates are basic contaminants occurring in food products and they make a considerable contribution into higher morbidity with specific nosologic forms, notably pathologies which are primarily caused by factors related to nutrition.

The paper focuses on analysis of laboratory research data on nitrates concentrations in food products; the data were collected in Altai region and they are taken from research reports issued by certified test laboratories. The authors also performed their own laboratory research at the Institute for Occupational Hygiene and Industrial Ecology of the RF Public Healthcare Ministry; it allowed to conclude that increased nitrates contents in food products were a vital issue which requires further examination and research performed with high precision laboratory research techniques.

We assessed hazard quotients (HQ) for nitrates occurring in vegetables and melons, individual carcinogenic risks (ICR), and population carcinogenic risks (PCR). Our hygienic assessment of nitrates concentrations in food products allowed us to reveal boundaries of risk properties variability.

It is necessary to work out recommendations how to reduce exposure of Altai region population to nitrates and to give grounds for priority approaches to administrative decision-making aimed at lowering population risks caused by consumption of nitrates-contaminated food products.

Key words: hygienic assessment, contamination with nitrates, monitoring, safety, food products quality, risk assessment.

\section{Introduction.}

To provide food safety for population in our country is a basic task which authorities in any region in the RF should solve. Altai region nowadays is a major producer and supplier of vegetable and animal food products both for its own population and people living in other regions; some products are also exported to the nearest countries. And as free economic zones such as the Customs Union and the Eurasian Economic Union are developing rapidly, this task is becoming even more significant.
Some hygienic problems are still to be solved in Altay region; for example, problems related to preventing various xenobiotics, including nitrates, from penetrating into food products at all the stages in their manufacturing, distribution, and storage. There are no well developed approaches to efficient population health preservation via more rational and optimal nutrition.

As per data taken from various research and works, vegetables, melons, and potato are most likely to be contaminated with ni-

(c) Saldan I.P., Shved O.I., Balandovich B.A., Nagornyak A.S., Mazko O.N., Makarova O.G., Filippova S.P., Zhukova O.V., Potseluev N.Yu., 2018

Igor' P. Saldan - Doctor of Medical Sciences, Professor (e-mail: rector@agmu.ru; tel.: +7 (3852) 56-68-02).

Ol'ga I. Shved - post-graduate student (e-mail: laukhina_olga@mail.ru; tel.: +7 (3852) 56-69-36).

Boris A. Balandovich - Doctor of Medical Sciences, Professor (e-mail: dr.balandovich@mail.ru; tel.: +7 (3852) 56-69-95).

Aleksei S. Nagornyak - post-graduate student (e-mail: tezaurismosis@gmail.com; tel.: +7 (3852) 56-69-36).

Olesya N. Mazko - Candidate of Medical Sciences, Senior Researcher (e-mail: noemail@agmu.ru; tel.: +7 (3852) 66-99-27).

Olesya G. Makarova - Candidate of Medical Sciences, Senior Researcher (e-mail: noemail@agmu.ru; tel.: +7 (3852) 66-99-27).

Sof'ya P. Filippova - Candidate of Medical Sciences, Associate Professor (e-mail: sofya.filippova@mail.ru; tel.: +7 (3852) 56-69-36).

Ol'ga V. Zhukova - Candidate of Medical Sciences, Associate Professor (e-mail: oov-@mail.ru; tel.: +7 8 (3852) 56-69-36).

Nikolai Yu. Potseluev - Candidate of Medical Sciences, Associate Professor (e-mail: pocelueff@mail.ru; tel.: +7 (3852) 56-69-36). 
trates $^{1,2,3}[1-3]$. Nitrates penetrate a human body in excessive doses due to vast application of nitrogen fertilizers in contemporary vegetable cultivation and due to nitrate compounds applied in food industry as preservatives and food additives, and it exerts adverse effects on health ${ }^{2,3}[2-4]$. If we assess nitrates contamination of food products which are sold in Altai region, it will allow us to estimate their contents in consumed food products and will help to implement prevention activities aimed at reduction of nitrates concentrations in food products. It is known that when some nitrates (about 5-7\%) are contained in food products in quantities higher than allowable concentrations, they can convert into nitrites in the gastrointestinal tract; and it is nitrites that exert adverse effects on a person's body and his or her health ${ }^{1}[5,6]$. When nitrites penetrate human blood, they make for ferrous iron oxidizing into ferric one, and it results in occurrence of hemiglobin which is unable to bring oxygen to body organs and tissues. Food products are a major way for nitrates to penetrate a body; first of all, we can mention vegetable products here (up to $80 \%$ nitrates enter a body with vegetables, including potatoes, melons, and fruit). Besides, nitrate can penetrate a body with drinking water and with medications $[2,4,7]$.

Nitrates hold a specific place among chemicals which are carcinogenic in their essence. Some research proves that they are related to malignant neoplasms emergence in the gastrointestinal tract [7]. Nitrates and nitrites are known to be authentic factors which cause higher stomach cancer risk as per data provided by authors who focus on issues related to influence exerted by food factors on carcinogenesis [8-10]. Research results reveal a significant correlation between oncologic tumors frequency and total load with mineral fertilizers and, consequently, nitrates [11, 12].

As a rule, hygienic assessment of food products is performed in specialized certified laboratories which makes for high quality products which are safe for consumers being sold on markets. Hygienic assessment of food products is to verify their conformity with the Customs Union Technical Regulations. Research related to nitrates concentrations in food products is regularly performed in Altai region by relevant test laboratories.

So, nowadays it is vital to hygienically assess nitrates contamination of food products on Altai region territory and to calculate risks of carcinogenic and non-carcinogenic effects caused by consumption of such products.

Research goal. Our goal was to assess nitrates contamination of food products manufactured and sold on Altai region territory and to assess risks related to consumption of such products by population in order to prevent adverse effects on a human body.

\section{Tasks.}

1. To assess nitrates contamination of food products produced and sold on Altai region territory via capillary electrophoresis.

2. To assess risks of emergence and growth in morbidity with certain nosologies under exposure to nitrates.

3. To work out scientifically grounded recommendations on improvement of laboratory control systems and prevention of alimentary-dependent diseases.

Data and methods. We took our data for retrospective analysis from official statistic reports provided by the Rospotrabnadzor re-

\footnotetext{
${ }^{1}$ MG 2.1.10.0062-12. Quantitative assessment of non-carcinogenic risk under exposure to chemicals based on evolution models design: methodical guidelines [Web-source]. - 2012. - P. 22. - URL: http://docs.cntd.ru/document/1200095225 (date of visit February 22, 2018).

${ }^{2}$ On sanitary-epidemiologic safety in the Russian Federation in 2013: State report [web-source]. - URL: http://rospotrebnadzor.ru/documents/details.php?ELEMENT_ID=1984 (date of visit February 22, 2018).

${ }^{3}$ On sanitary-epidemiologic safety in the Russian Federation in 2015: State report [web-source]. - URL: $\mathrm{http} / / /$ rospotrebnadzor.ru/documents/details.php?ELEMENT_ID=6851 (date of visit February 22, 2018).
} 
gional office in Altai region collected over 2011-2015.,3. More than 70,000 laboratory test results were analyzed; 13,000 out of them were analyzed in terms of their conformity to hygienic standards of nitrates contents in food products. All the data were statistically processed as per conventional techniques in Microsoft Excel 2013.

To determine nitrates contents in food products, we performed our research at the Institute for Occupational Hygiene and Industrial Ecology of Altai State Medical University; various vegetables such as cucumbers, tomatoes, cabbage, beetroot, onion, potatoes, and marrows brought from different Altai region territories (Barnaul, Ust'-Pristanskiy, Petropavlovskiy, and Zav'yalovskiy districts) were analyzed with the capillary electrophoresis technique [13-15]. This technique is based on separating components in a complicated mixture in a crystal capillary under exposure to applied electric field and it allows to examine micro-volumes of a sample. Confinement parameter (migration time) is a qualitative characteristics of a substance, and a peak height or square proportionate to a substance concentration is its quantitative characteristics [13]. Range of nitrate-ions measuring with capillary electrophoresis amounts to $5.0-50.0 \mathrm{mg} / \mathrm{l}$, a relative measurement uncertainty here being equal to $10 \%$. It was the first time when this technique was applied to examine nitrates contents in food products in Altai region. 189 food products samples were examined with it; they were chosen as research objects within scientific research NIR No. 02-18 planned in accordance with a working program for a postgraduate student training and research schedules approved in the Institute for Occupational Hygiene and Industrial Ecology of Altai State Medical University.
Carcinogenic risk caused by exposure to nitrates was assessed as per the Guidelines on assessment of population health risks under exposure to chemicals which pollute the environment ${ }^{4}$. We took average food products consumption in the region as our basic scenario. Consumption parameters were determined according to official data provided by the Federal Statistic Service, to be exact, its regional offices in Altai region and Altai Republic [16]. We calculated average annual consumption of each product per 1 person. A body weight of an adult man was considered to be equal to $70 \mathrm{~kg}$. Average daily nitrates doses were calculated as per average values for nitrates contents in examined food products.

We calculated individual carcinogenic risk with a modified exponential model ${ }^{2,3,5}$ $[5,7]$ :

$$
I C R=\exp \left(1,44 \cdot 10^{-7} K\right)^{-1}
$$

where

ICR is individual carcinogenic risk;

$\mathrm{K}$ is a quantity of nitrates which penetrated a body, mg/person/day.

Population carcinogenic risk was calculated as per a conventional technique [7]:

$$
P C R=I C R \cdot P O P,
$$

where

PCR is population carcinogenic risk;

POP is a number of people in an examined population, people.

To assess non-carcinogenic risks, we applied a hazard quotient (HQ) ${ }^{1}$ [7] and a mathematical model ${ }^{2,3}[5,7]$ :

$$
\Delta R=0,00052\left\langle\frac{1}{1+e^{-(-6,89+0,04 K)}}-\frac{1}{1+e^{-(-6,89+0,04 \cdot 1,6)}}\right\rangle,
$$

where $\Delta R$ is a non-carcinogenic risk growth.

${ }^{4} \mathrm{P}$ 2.2.1.10.1920-04. Guidelines on assessment of population health risks under exposure to chemicals which pollute the environment. - M.: Federal Center for State Sanitary and Epidemiologic Surveillance of the RF Public Healthcare Ministry, 2004. - $143 \mathrm{p}$.

${ }^{5}$ MY 2.3.7.2519-09 Determination of exposure and assessment of population health risks caused by chemical contaminants contents in food products. Methodical guidelines. - M.: Rospotrebnadzor's Federal Center for Hygiene and Epidemiology, 2010. -27 p. 
Results and discussion. We detected that experts from a test laboratory center at the Altai Center for Hygiene and Epidemiology examined 70,000 food products samples over 5 years, 2011-2015. The share of samples which didn't conform to hygienic standards varied from $0.1 \%$ to $2.0 \%$. In 2011 nitrates contents were higher than hygienic standards in $0.3 \%$ samples (vegetables, potatoes, and herbs). All the non-conforming samples were domestic products. In 2012 specific weight of samples not conforming to hygienic standards as per nitrates contents grew to $0.4 \%$. In 201314 fruit and vegetables samples out of 2,800 examined ones deviated from hygienic standards as per nitrates contents which accounted for $0.5 \%$ of the overall samples quantity. In 201428 out of 2,333 samples didn't conform to hygienic standards as per nitrates contents. Samples of fruit, vegetables, and melons deviated from standards most frequently. All the nonconforming samples taken in 2014 were domestic products. Specific weight of food products samples and food raw materials which didn't conform to hygienic standards amounted to $1.2 \%$ in 2014. In 20154 fruit and vegetables samples out of 2,289 examined ones deviated from hygienic standards as per nitrates contents which accounted for $0.2 \%, 3$.

We applied capillary electrophoresis technique in a laboratory at the Institute for Occupational Hygiene and Industrial Ecology to examine 189 samples of vegetables. Nitrates concentrations detected during food products examination ranged from $21.2 \pm 2.4 \mathrm{mg} / \mathrm{kg}$ to $1619.0 \pm 12.3 \mathrm{mg} / \mathrm{kg}$ of a product mass, average values here ranging from $46.0 \pm 1.7 \mathrm{mg} / \mathrm{kg}$ in marrows to $678.3 \pm 15.8 \mathrm{mg} / \mathrm{kg}$ in beetroot, as we can see in Figure 1.

As per statistic data provided by the Altai Regional Office of the Federal Statistic Service, vegetables, melons, potatoes, fruits and berries account for a considerable share of the overall food products consumption and are a significant part in Altai population food ration (Figure 2). They account for $31.6 \%$ of an aver- age statistical ration, share of potatoes being equal to $10.8 \%$; that of melons and vegetables, $12.4 \%$.

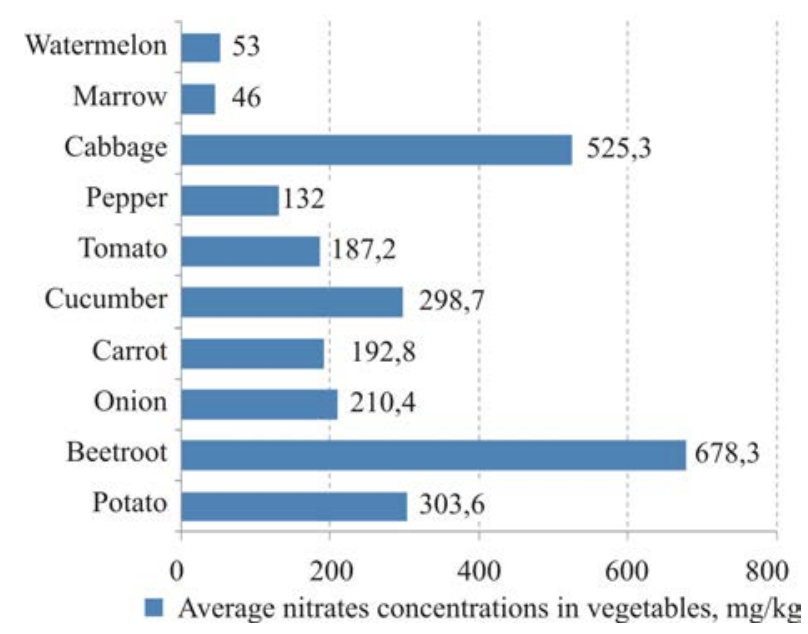

Figure 1. Average nitrates concentrations in various vegetables

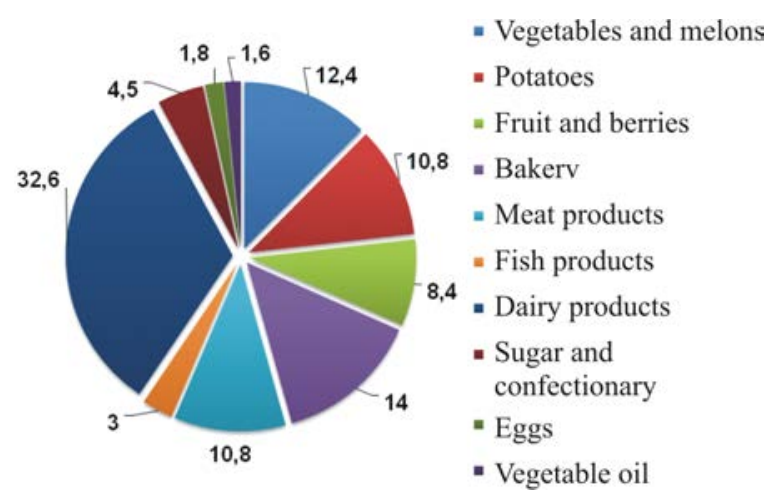

Figure 2. Shares of various food products in population ration in Altai region

We calculated average daily nitrates doses which penetrated a body with vegetables and potatoes; to do that, we determined average nitrates concentrations in examined vegetables (Figure 3). Average doses in which nitrates penetrated a body amounted to $170 \mathrm{mg}$ /day in Altai region $(77.4 \mathrm{mg} /$ day were introduced with potatoes; $92.6 \mathrm{mg} /$ day, with other vegetables).

We detected that cucumbers, onion, and potatoes made the greatest contribution into exposure to nitrates in Altai region. Excessive nitrates concentrations which were higher than MPC were detected in those products were 
registered most frequently; these concentrations also exceeded MPC greater than concentrations in any other products (Figure 4).

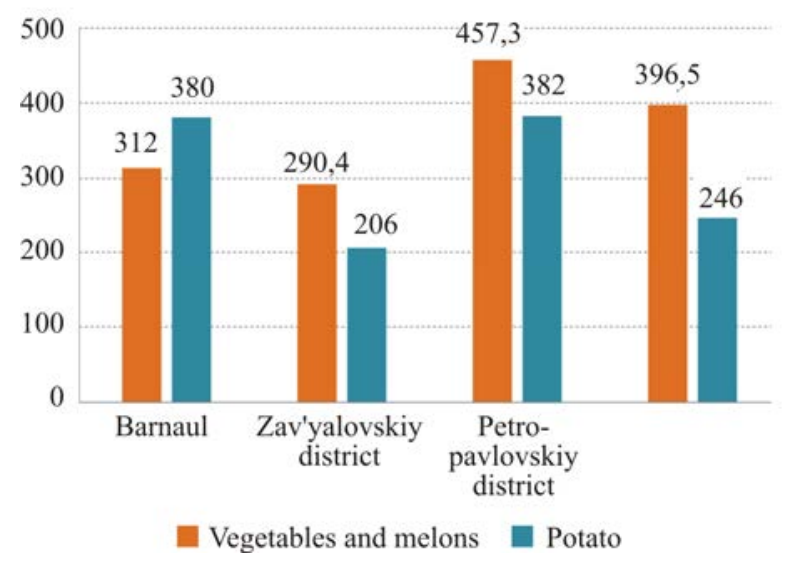

Figure 3. Average nitrates concentrations in food products, $\mathrm{mg} / \mathrm{kg}$

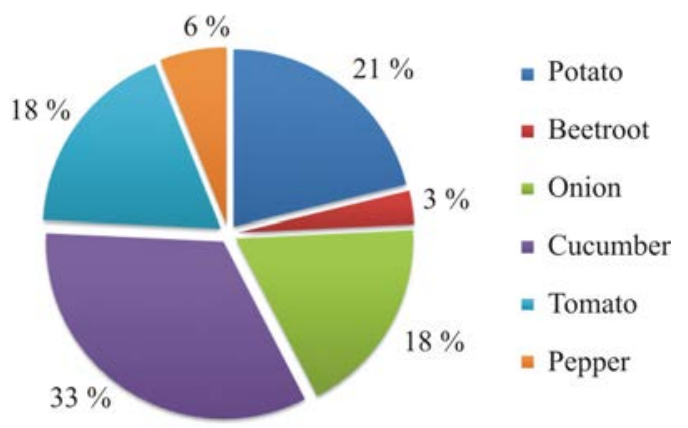

Figure 4. Specific weight of various vegetables in overall volume of products not conforming to hygienic standards as per nitrates concentration

Our calculation of individual carcinogenic risks (ICR) revealed that there was an additional probability that malignant neoplasms could emerge in a person during his or her life time. Carcinogenic risk could be estimated as low for all the examined territories in Altai region $\left(1 \cdot 10^{-6}-1 \cdot 10^{-4}\right)$; the maximum individual carcinogenic risk was detected on the examined territory, Petropavlovskiy region $\left(3.2 \cdot 10^{-5}\right)$. Though ICR is considered to be low, nevertheless, it is higher than permissible (which is lower than $1 \cdot 10^{-6}$ ); therefore, it makes a certain contribution into a probability that such pathology as a malignant neoplasm can emerge in an individual, as we can see on Figure 5.
Population carcinogenic risk shows a number of malignant neoplasms cases which occur in an examined population in addition to a background risk level. Individual and population carcinogenic risks show upper limit of possible carcinogenic risk for a period which is equal to an average life time of an individual (70 years) $[5,7]$.

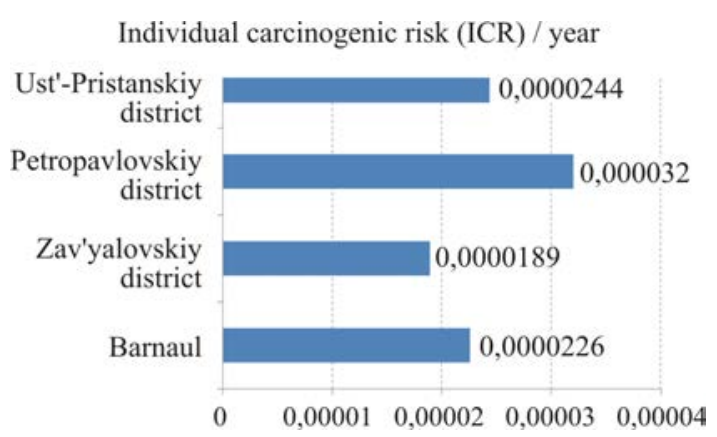

Figure 5. Individual carcinogenic risks caused by vegetables contamination with nitrates on different territories in Altai region

A carcinogenic process is a random one; it has long-term latent period; there are a lot of differences in age sensitivity to it; and a probability of death outcome for each individual is difficult to determine as it is time- and agedependent. Therefore, it is next to impossible to try and predict terms in which malignant neoplasms can occur even on the basis of all the available scientific data.

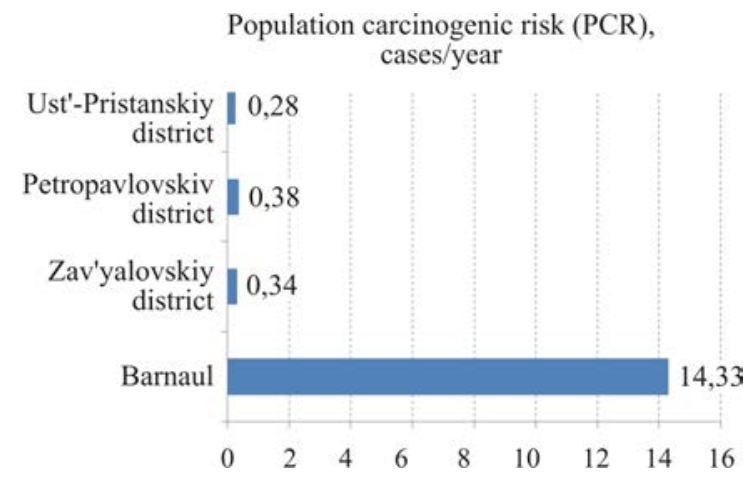

Figure 6. Population carcinogenic risks caused by exposure to nitrates on different territories in Altai region

As we can see from Figure 6, contamination of food products with nitrates makes a certain contribution into morbidity with ma- 
lignant neoplasms due to additional cases of the disease in population living on different territories in Altai region. 14 additional cases beyond the background level were detected in Barnaul; tentatively 1 additional case of the disease in three years was detected in Ust'Pristanskiy, Petropavlovskiy, and Zav'yalovskiy districts due to population number in these three regions being considerably smaller than in Barnaul (more than 20 times smaller).

Our estimation of hazard quotients for nitrates contained in fruit and vegetables revealed that their values were not higher than 1 ; it allowed us to conclude that effects exerted by nitrates on population health could be considered permissible provided that they entered a body in calculated doses during life time. Yet, should nitrates penetrate a human body in doses higher than calculated ones, HQ value can become higher than permissible one, and it will lead to greater hazardous influence exerted by nitrates and possible carcinogenic and non-carcinogenic effects in population living in the region. Thus, the hazard quotient in Petropavlovskiy region is already close to 1 , which means there is a greater possibility there that hazardous effects can occur when population consumes food products which contain calculated nitrates doses.

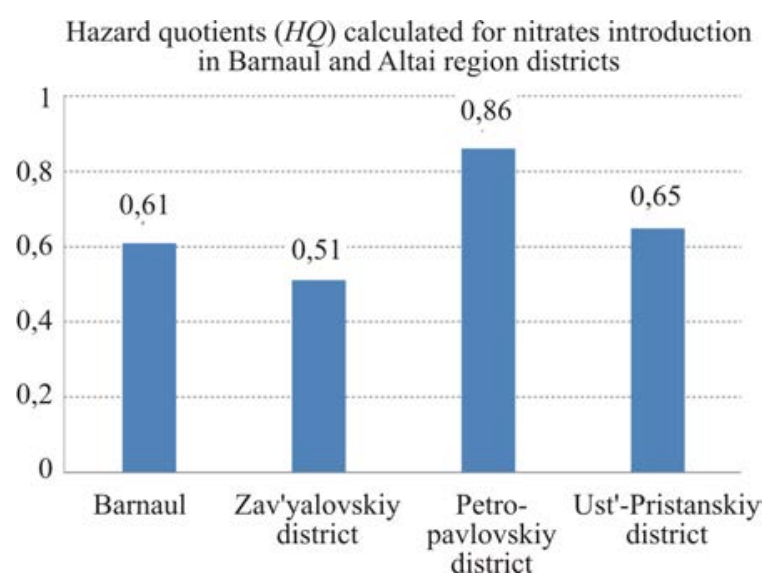

Figure 7. Hazard quotients (HQ) calculated for nitrates introduction in Barnaul and Altai region districts

\section{Conclusion.}

We analyzed available data obtained via laboratory research concerning nitrates contents in food products in Altai region. We detected that some vegetable products contained nitrates in concentrations higher than MPC. Excessive nitrates quantities were detected in vegetables (including potato and onion), herbs, melons and watermelons. Our own research revealed that such vegetables as cucumber, tomato, and onion, were most contaminated with nitrates.

Assessment of hazard quotients (HQ) for nitrates contained in vegetables and melons allows to consider influence exerted by nitrates on population health to be permissible provided that nitrates penetrate a body in calculated doses during life time. But at the same time, should nitrates penetrate a body in doses higher than calculated ones, it can cause HQ values become higher than permissible ones.

Individual carcinogenic risk (ICR) caused by nitrates concentrations in food products is estimated as low. ICR determined by nitrates contents in food products varies from $1.89 \cdot 10^{-5}$ to $3.2 \cdot 10^{-5}$. Such risk level doesn't require any additional measures aimed at its reduction; still, it is subject to selective periodic control as it makes a certain contribution into a probability of malignant neoplasms occurrence in population.

Value of population carcinogenic risk (PCR) caused by nitrates contents in food products allows us to assume that there is a possibility of $0.28-14.33$ malignant neoplasms cases occurring in population living on the examined territories which are additional to the background oncologic morbidity.

Funding. The research was not granted any sponsor support.

Conflict of interests. The authors state there is no any conflict of interests. 


\section{References}

1. Kislitsyna L.V. Otsenka soderzhaniya khimicheskikh kontaminant v produktakh pitaniya zhitelei Primorskogo kraya [Assessment of chemical contaminants concentrations in food products consumed by Primorskiy region population]. Zdorov'e. Meditsinskaya ekologiya. Nauka, 2011, vol. 46, no. 3, pp. 36-42 (in Russian).

2. Habermeyer M., Roth A., Guth S., Eisenbrand G., Diel P. [et al.] Nitrate and nitrite in the diet: how to assess their benefit and risk for human health. Molecular Nutrition and Food Research, 2015, vol. 59, no. 1, pp. 106-128.

3. Lucas Reijnders, Food safety, environmental improvement and economic efficiency in the Netherlands. British Food Journal, 2004, vol. 106, no. 5, pp. 388-405.

4. Poortmans J.R., Carpentier A., Gualano B. Nitrate supplementation and human exercise performance: too much of a good thing? Current Opinion in Clinical Nutrition and Metabolic Care, 2015, vol. 18, no. 6, pp. 599-604. DOI: 10.1097/MCO.0000000000000222.

5. Onishchenko G.G., Zaitseva N.V., May I.V. [et al.]. Analiz riska zdorov'yu v strategii gosudarstvennogo sotsial'no-ekonomicheskogo razvitiya: monografiya [Health risk analysis in the strategy of state social and economical development: monograph]. In: G.G. Onishchenko, N.V. Zaitseva eds. Moscow, Perm, Perm National Research Polytechnic University Publ., 2014, 738 p. (in Russian).

6. Ximenes M.I., Rath S., Reyes F.G. Polarographic determination of nitrate in vegetables. Talanta, 2000, vol. 51, no. 1, pp. 49-56.

7. Shur P.Z., Kir'yanov D.A., Atiskova N.G., Chigvintsev V.M., Khrushcheva E.V. Obosnovanie dopustimykh urovnei soderzhaniya nitratov $\mathrm{v}$ rastenievodcheskoi produktsii po kriteriyam riska zdorov'yu [Justificaion of acceptable nitrate levels in crop product using health risk criteria]. Zdorov'e naseleniya i sreda obitaniya, 2013, vol. 248, no. 11, pp. 47-48 (in Russian).

8. Lazarev V.V. Problema zabolevaemosti zlokachestvennymi novoobrazovaniyami v Omskoi oblasti [Morbidity with malignant neoplasms in Omsk region]. Bezopasnost' gorodskoi sredy: materialy mezhregional'noi nauchno-prakticheskoi konferentsii s mezhdunarodnym uchastiem [Urban environment safety: materials of theoretical and practical conference with international participation]. 2016, pp. 209-211(in Russian).

9. Deryagina V.P., Krivosheeva L.V., Savluchinskaya L.A., Golubeva I.S., Ryzhova N.I. Mekhanizmy realizatsii modifitsiruyushchego deistviya nitritov na kantserogenez [Modifying impacts exerted by nitrates on carcinogenesis: implementation mechanisms]. Novye informatsionnye tekhnologii v meditsine, biologii, farmakologii i ekologii: Materialy Mezhdunarodnoi konferentsii [New information technologies in medicine, biology, pharmacology and ecology: International conference materials]. In: E.L. Gloriozova ed. Gursuf-Yalta, 2017, pp. 185-191 (in Russian).

10. Boev V.M., Kuksanov V.F., Bystrykh V.V. Khimicheskie kantserogeny sredy obitaniya i zlokachestvennye novoobrazovaniya [Chemical carcinogens in the environment and malignant neoplasms]. Moscow, Meditsina Publ., 2002, 175 p. (in Russian).

11. Suleimanova N.D. Ekologicheskie aspekty zlokachestvennykh novoobrazovanii zhenskikh polovykh organov [Environmental aspects of malignant neoplasms of female genital organs]. Vestnik Dagestanskoi gosudarstvennoi meditsinskoi akademii, 2016, vol. 18, no. 1, pp. 75-79 (in Russian).

12. Davydov M., Demidov L., Polyakov B. Sovremennoe sostoyanie i problemy onkologii [Oncology: contemporary state and issues]. Vrach, 2006, no. 13, pp. 3-7 (in Russian).

13. Khomov Yu.A., Fomin A.N. Kapillyarnyi elektroforez kak vysokoeffektivnyi analiticheskii metod (obzor literatury) [Capillary electrophoresis as the high effective analytical method (review of the literature)]. Sovremennye problem nauki I obrazovaniya, 2012, no. 5, p. 349 (in Russian).

14. Velikinac I., Cudina O., Janković I., Agbaba D., Vladimirov S. Comparison of capillary zone electrophoresis and high performance liquid chromatography methods for quantitative determination of ketoconazole in drug formulations. Farmaco, 2004, vol. 59, no. 5, pp. 419-424. DOI: 10.1016/j.farmac.2003.11.019. 
15. Quaglia Giovanna M. [et al.]. Determination of fenticonazole and its impurities by capillary electrophoresis and high performance liquid chromatography. J. of High Resolution Chromatography, 2001, vol. 24, no. 5, pp. 392-396.

16. Potreblenie produktov pitaniya $\mathrm{v}$ domashnikh khozyaistvakh Altaiskogo kraya [Food products consumption in Altai region households]. Federal'naya sluzhba gosudarstvennoi statistiki po Altaiskomu krayu i Respublike Altai: Ofitsial'nyi sait. Available at: http://akstat.gks.ru/wps/wcm/connect/rosstat ts/ akstat/resources/929513804e9856abb99cbba638e2bbf1/\%D0\%9F\%D0\%BE\%D1\%82\%D1\%80.\%D0\% BF\%D1\%80\%D0\%BE\%D0\%B4.\%D0\%BF\%D0\%B8\%D1\%82\%D0\%B0\%D0\%BD\%D0\%B8\%D1\%8F.h tm (10.02.2018) (in Russian).

Saldan I.P., Shved O.I., Balandovich B.A., Nagornyak A.S., Mazko O.N., Makarova O.G., Filippova S.P., Zhukova O.V., Potseluev N.Yu. Assessment of risks caused by impacts exerted on a human body by nitrates contained in food products. Health Risk Analysis, 2018, no. 2, pp. 81-88. DOI: 10.21668/health.risk/2018.4.09.eng

Received: 02.03 .2018

Accepted: 01.06.2018

Published: 30.12.2018 